\title{
4
}

\section{AOTEAROA NEW ZEALAND \\ Participatory science and bicultural knowledge communication}

\author{
Jean S. Fleming, Nancy Longnecker, Rhian A. Salmon, \\ and Daniel C. H. Hikuroa
}

\section{Introduction}

Science communication continues to evolve internationally as a field of study (Gascoigne et al., 2010; Trench, 2012). In Aotearoa ${ }^{1}$ New Zealand (NZ), there have been increased opportunities in education, jobs, funding and prizes related to science communication. NZ's bicultural status, as defined by the Treaty of Waitangi (Hudson and Russell, 2009; Mohi and Roberts, 2009; Orange, 2011), provides a unique cultural context within which scientific research and science communication occur. Fleming and Star (2017) have previously documented the history of emergence and development of Western science communication in NZ. An overview is presented in the timeline at the end of the chapter. In this chapter we further explore some specific aspects of the science communication ecosystem in NZ, as well as drivers behind a notable shift towards more participatory science and science communication.

New Zealanders have a strong history of acting firmly and independently, as demonstrated by the banning of nuclear-powered or armed ships in 1984 despite the country's strong alliance with the United States. Aotearoa New Zealand's strong kaitiaki (guardianship) ethic, especially amongst Māori, but also amongst Pākehā (non-Māori) New Zealanders, has empowered environmental activism. For example, the successful Save Manapouri

1 Aotearoa is a Māori name for New Zealand's North Island and is often used as a name for the entire country. 
Campaign ran from 1969 to 1972; not only did it prevent the raising of the level of Lake Manapouri for construction of the Manapouri Power Project (Mark and Johnson, 1985; Mark, 2001, 2015), it also influenced the results of a federal election.

This independent streak is reflected in the way NZ has moved to accept the value of indigenous knowledge ahead of other countries. The past decades have seen a significant shift in the way in which indigenous knowledge, knowledge systems and engagement processes are respected and incorporated into nationwide funding, research practice and public engagement. As discussed in more detail later, NZ has a Vision Mātauranga policy, which recognises the potential of mātauranga (Māori knowledge, culture, values and world view) and its value to current research projects. The Ministry of Business, Innovation and Employment holds that Vision Mātauranga 'unlocks the science and innovation potential of Māori knowledge, resources and people' (MBIE, 2018).

Independence has made the country more cautious about scientific advances. The development of new technologies such as genetic modification and nanotechnology has led to an increase in public mistrust of science (Hipkins et al., 2002). The initial response of scientists and science institutions to this caution about new technologies was to provide more information, to fill a perceived 'deficit' in knowledge in the public. This was driven perhaps by the traditions of the Royal Society of London after the release in 1985 of the Bodmer Report on the Public Understanding of Science (Collins and Bodmer, 1986; Pieczka and Escobar, 2013). In NZ and around the world, scientists, educators and policy makers worked to increase public awareness and acceptance of evidence-based science and knowledge (Bucchi, 1998; Wilsdon and Willis, 2004; Munshi et al., 2016; Smallman, 2016).

In the early part of the 21 st century, science communicators began to stress the importance of dialogue with the public (Bucchi, 2008; Cronin, 2008; France et al., 2012; Green and Rohan, 2012; Zorn et al., 2012). In NZ, public consultation played an important role in the government's establishment of 11 National Science Challenges in 2013 (described below). A potential opportunity for further research into science communication specific to the NZ context was missed when the proposed 12th National Science Challenge, which would have specifically addressed science in society, was not funded in the same way as the other challenges. Nevertheless, the value of science communication was recognised and each of the National Science Challenges has an imperative to engage with a variety of stakeholders, including the public. 
By 2015, the value of participatory science projects was accepted by scientists, policy makers and funders (Peters, Eames and Hamilton, 2015; Galbraith et al., 2016; Peters et al., 2016; Sullivan and Molles, 2016; Storey and WrightStow, 2017; Blake et al., 2018). A relatively small but important new national funding initiative, Unlocking Curious Minds, ${ }^{2}$ was announced in 2014 with the intent of fostering participatory science and stimulating engagement of all New Zealanders with science, particularly those who may otherwise be cut off from access to science education and outreach (New Zealand Government, 2018b). Partially as a result of these initiatives, participatory science and science communication has developed rapidly over the past five years in NZ, especially in the area of environmental monitoring and data gathering, as scientists' trust of data gathered by community participants increases and the pool of funding expands (Peters, Eames and Hamilton, 2015; Peters et al., 2016).

\section{Human settlement of Aotearoa New Zealand and early practice of science}

The most recent Māori settlers arrived in NZ around 750 years ago (McWethy et al., 2009; Seersholm et al., 2018), equipped with unparalleled oceanvoyaging technology and navigation and observation skills. Mātauranga includes knowledge generated using techniques consistent with the scientific method, but explained according to a Māori worldview (Hikuroa, 2017). The arrival of Māori in NZ rapidly introduced large-scale changes, with systematic burning of about half of the forest cover and hunting of the large, flightless moa (Aves: Dinornithiformes) to extinction within a few hundred years (McWethy et al., 2014).

The first European visitors came to NZ in 1642 and by the late 18th century the country was regularly visited by explorers, scientists and naturalists. They were keen to collect new species of plant or animal or to observe the transit of Venus (Fleming, 1987; Priestley, 2010). The arrival of colonisers from the Northern Hemisphere in the 18th and 19th centuries led to further changes in land use, including additional clearance of native forest cover and systematic draining of wetlands. Commercialised hunting of whales led to localised extinctions, and the collection of museum specimens in the

2 The Unlocking Curious Minds contestable fund supports the objective of A Nation of Curious Minds - He Whenua Hihiri I te Mahara to encourage and enable better engagement with science and technology across all of New Zealand, see www.mbie.govt.nz/science-and-technology/science-andinnovation/funding-information-and-opportunities/investment-funds/unlocking-curious-mindscontestable-fund/. 
pursuit of science led to further extinctions, including the huia (wattlebird) (Lambert et al., 2009). The signing of the Treaty of Waitangi in 1840 (Bess, 2011; Orange, 2011) was supposed to ensure that the property rights of Māori remained after the Crown acquired sovereignty over their territories (Bess, 2011). Some of the first visitors from the Northern Hemisphere were scientists who studied the geology and natural history of NZ (Fleming, 1987; Priestley, 2008), and science communication in its current Western manifestation started with these pioneer scientists as they reported their findings both to the NZ Government and back 'home' to Great Britain. Mātauranga remained largely in the private domain of Māori, being regarded as superstition or myth by non-Māori scientists (Broughton and McBreen, 2015) until the end of the 20th century, when different perspectives on science became more valued (Hikuroa, 2017).

\section{Scientific institutions and government policy}

As the European population grew, institutes and museums were quickly established, and public lectures and meetings on the new geological or natural history findings were common (Priestley, 2008). The first colonial scientific and philosophical institutions, along with museums, were established in NZ in the mid to late 19th century (Priestley, 2010; Fleming, 1987). The Royal Society Te Apārangi (updated name officially announced in 2017) was founded in 1868 and published its Transactions from that date. Publicly acknowledged scientific research in the late 19th century was largely performed and selffunded by 'Victorian gentlemen', who earned income from professions such as the law or medicine and 'had a goal of demonstrating the power of science to further the common good' (Martin, 2017). As the universities were established (the University of Otago in 1869 and Canterbury College, part of the University of New Zealand, in 1873), salaried scientists and technical staff were more common (Martin, 2017).

The NZ Government established the Department of Scientific and Industrial Research (DSIR) in 1926, to drive research and innovation in natural sciences, agriculture and industry. As a new workforce grew, the New Zealand Association of Scientific Workers (later the NZ Association of Scientists; NZAS) was formed in 1942. The first issue of their journal New Zealand Science Review soon followed. This group also established NZ's first award for science communication in 1990 (Gregory, 2017). By the 1970s, many NZ scientists worked directly for the government as public servants in the DSIR (Galbreath, 1998). 
In the early 1990s, DSIR was disestablished and the National Government restructured the science scene, creating in its place the Ministry of Research, Science and Technology, the Foundation for Research, Science and Technology (both of which have subsequently been further restructured) and the Crown Research Institutes (CRIs), of which there were originally 10 (Martin, 2017). There was more emphasis placed on obtaining external funding for research and on research for commercialisation. The push for modern developments in science communication gradually gained support from the scientific community, as many perceived a need to gain acceptance for new ideas or technologies (Douglas, 1988; Levitin, 2015; Csiszar, 2017), as well as a need to communicate clearly during natural disasters, such as earthquakes and volcanoes (Orchiston, 2010; Blake et al., 2018) or biosecurity emergencies (Bewsell et al., 2012; Warner, 2012; Muellner et al., 2018).

A Public Good Science Fund and a number of Centres of Research Excellence (CoREs) were established in the early 2000s (McCarthy and Rands, 2013; Martin, 2017). As commercial imperatives increased, the CRIs started producing their own public relations material, often bypassing the scientists themselves (Ashwell, 2016). Given NZ's geography and relatively small population size, there were few major daily newspapers and no public broadcasting television channels. Newsroom restructuring exacerbated a drop in the number of science journalists, diminishing independent science reporting (Ashwell, 2016). Ashwell (2016) revealed differences in opinion about the standard of science journalism between scientists and the communication advisors: scientists maintained that science reporting was poor, while communication advisors said their organisations were generally reported well. Furthermore, it has been noted that communication teams from CRIs, universities and science industries are often more interested in messaging, fundraising or creating a particular public image than reporting objectively (Salmon and Priestley, 2015). However, both scientists and communication advisors brought up issues of newsroom restructuring and increased pressures on science journalists, with cutbacks to personnel resulting in an increased use of press release material by journalists, often verbatim (Ashwell, 2016).

A publicly funded Science Media Centre was established in 2008 (Salmon and Priestley, 2015) to better inform journalists of current scientific research results. Concerns remain about the ability for publicly funded scientists to speak openly about their research results and expertise (Griffin, 2014; Hendy, 2016), as 40 per cent of those surveyed by the NZAS indicated in 2014 (Griffin, 2014). 
The position of the NZ Prime Minister's Chief Science Advisor was established in 2009 to provide scientific advice and inform government policy with scientific evidence. Professor Sir Peter Gluckman held the inaugural position until mid-2018, when Professor Juliet Gerrard was appointed. The roles of the position now include raising the profile of science in NZ, especially amongst young people, making science more accessible to the public and encouraging the science community to build trusted relationships with communities (OPMCSA, 2018). The success of the Prime Minister's Science Advisor role also led to the creation of further science advisor roles being embedded within several government ministries (or departments) (MBIE, 2016).

In 2013, the government established a National Science Challenges panel, consisting of members of the public as well as science stakeholders and chaired by Sir Peter Gluckman, to prioritise research funding related to important national issues (Gluckman, 2013). The findings of this panel led to a major restructuring of the national funding of scientific research in 2013 (Salmon and Priestley, 2015). The National Science Challenges initiative aimed to promote greater commercial applications of scientific knowledge, reflecting ongoing neoliberal reforms by the National Party Government in NZ (Prussing and Newbury, 2016). They were also meant to lead to greater public engagement with science (Leitch et al., 2014). Eleven National Science Challenges were announced, focusing on environmental issues (land and water, resilience to nature, climate change, biological heritage, sustainable seas); health issues (child health, ageing populations, healthy living, nutrition); technological issues (science for technological innovation); or a combination of these (building better homes, towns and cities). These all became large, 'mission-led', interdisciplinary research programs with a substantial public or sector engagement component (Gluckman, 2013; MBIE, 2013).

The conclusions of the National Science Challenge panel's report stated that 'deficits' in the public's understanding of science needed addressing (Salmon and Priestley, 2015), suggesting sympathy for a 'deficit' approach to science communication. The proposed 'remedy' to this was the establishment of a 12th challenge, focused on 'Science and Society'. Rather than outsourcing this to research organisations, as occurred for the other 11 challenges, the government chose to manage this component internally.

As a result, in 2014, the previously mentioned strategy (A Nation of Curious Minds - He Whenua Hihiri I te Mahara) was officially launched (New Zealand Government, 2018a). It was designed to fund projects bringing science to society, thereby enabling better engagement with science and technology for all New Zealanders. Two funding initiatives were launched to support the strategy: A Nation of Curious Minds and three pilot participatory 
science platforms (launched in 2015) (New Zealand Government, 2018a), indicating the desire of the government to move towards more dialogic, participatory science communication. The resultant support from the public, scientists and government for participatory science appears to have informed the views of significant decision-makers in the science establishment who previously tended towards a deficit approach to science communication.

While there is a place for experts sharing their knowledge in a deficit-style approach, a broader participatory approach to science and its communication is now widely thought to be more effective (Bucchi, 2008; Salmon and Priestley, 2015; Longnecker, 2016a). A NZ example of ineffective use of a deficit, non-dialogic approach is described in a section below, 'Seeing science differently: Indigenous science and community engagement'.

\section{A new kind of science communication in Aotearoa New Zealand}

As discussed in more detail by Fleming and Star (2017), much of NZ's recent public engagement with scientific issues has been fuelled by health-related issues and by grassroots environmental movements. As in other modern societies with ageing populations, socioeconomic inequities and significant indigenous populations, NZ faces numerous public health challenges. The desire to protect the environment is also strong and multi-pronged, as tourism is a major contributor to the local economy and the natural environment is a key attraction for visitors (Fiedler et al., 2008). Science communication has a significant role to play in addressing these challenges.

However, the increase in communication of science has not just been driven by health-related issues and conservation of native plants and animals. Increasing frequency of physical disasters such as storms, flooding events and coastal erosion has hit society hard, from the smallest communities to our largest cities, and the growing cost of climate change to citizens and governments is becoming clear (Gifford et al., 1996; Ministry for the Environment, 2008; Roper et al., 2016; Royal Society of New Zealand, 2016). Furthermore, the rise in awareness of single-use plastic pollution (Gregory, 1978; Klein, 2018), the need to reduce the amount of waste going to landfill (Davies, 2009), the deterioration of NZ's freshwater and the decline of native freshwater fish (Joy et al., 2018), and the spread of pathogens such as myrtle rust and Mycoplasma bovis have all contributed to fierce debate of these environmental issues. 
Changes in New Zealanders' attitudes to science were observed through the 2000s (Fleming and Star, 2017). The most recent survey, released in March 2018 and entitled Public Engagement with Science \& Technology, shows 90 per cent of New Zealanders are interested in learning about science and 60 per cent feel well informed about science. However, New Zealanders are less likely to feel that science is important in their lives and almost a third feel science has become too specialised, with too much conflicting information making it hard to know what to believe (Nielsen Research, 2018).

In spite of diverse support, there are challenges to unfettered science communication. Hendy (2016) proposes that the lack of depth in some fields in NZ means that scientists cannot retreat from public communication but have an obligation to engage. He goes further to suggest that NZ scientists may need to adopt the potentially controversial role of advocate. He makes an eloquent case for greater communication to the $\mathrm{NZ}$ public about the practice of science (Longnecker, 2016b).

Below we discuss three aspects of science communication that play a significant role in influencing the national science communication ecosystem of NZ. These are environmental issues, hazards and disasters, and indigenous science and community engagement. These are by no means representative of the full scope of either the scientific issues that drive this work or the science communication activities that occur; for example, climate change communication is increasingly important in NZ (Salmon et al., 2017). Similarly, an exploration of the many health-related communication initiatives would warrant an article of its own and is beyond the scope of this chapter. We conclude this chapter with an overview of the increase in science communication training and education that has occurred over recent years.

\section{Environmental issues, communication and citizen science initiatives}

NZ has many species listed as in danger of extinction from habitat loss and predation by introduced predators (Dowding and Murphy, 2001; St Clair, 2011; Norbury and Jones, 2015; Ruffino et al., 2015; Thoresen et al., 2017). In the 1980s and 1990s, there was an upsurge in conservation initiatives by community groups in response to the decline in native bird numbers. Amongst other initiatives, this led to the establishment of fenced ecosanctuaries, such as Zealandia (originally the Karori Wildlife Sanctuary) near Wellington (Campbell-Hunt, 2002) and Orokonui Ecosanctuary near Dunedin (Tanentzap and Lloyd, 2017). There are now well over 20 ecosanctuaries in 
$\mathrm{NZ}$ and its offshore islands, which act to exclude introduced mammalian predators (possum, rat, cat, dog, ferret, weasel and stoat) and browsers and grazers (possum, rabbit, pig, goat and deer) to enable native ecologies to re-establish and sustain local flora, bird, lizard and insect populations (Campbell-Hunt and Campbell-Hunt, 2013).

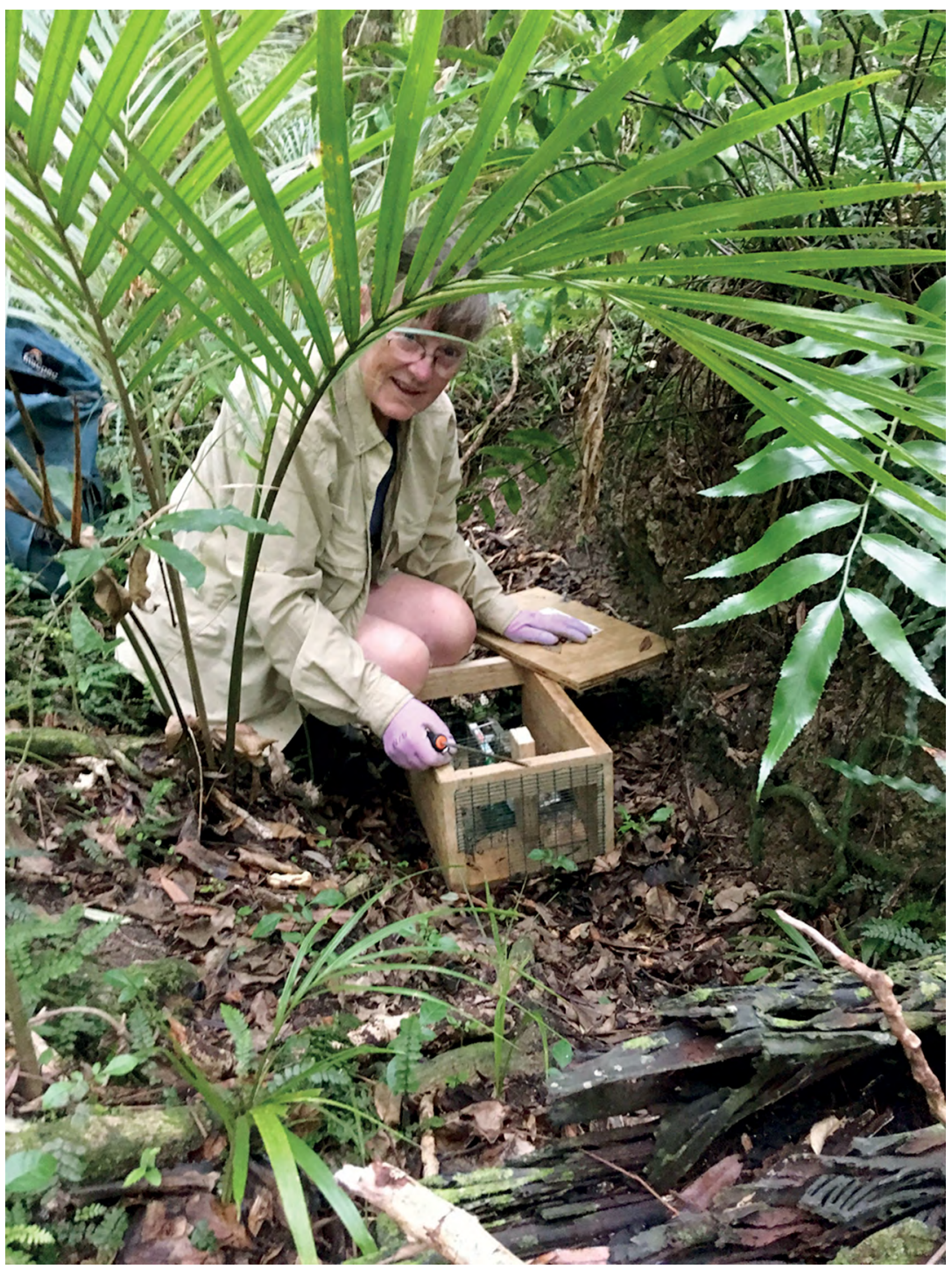

Figure 4.1: A volunteer checks a stoat trap in dense bush near Wellington, New Zealand.

Source: Photo courtesy of Jean Fleming. 


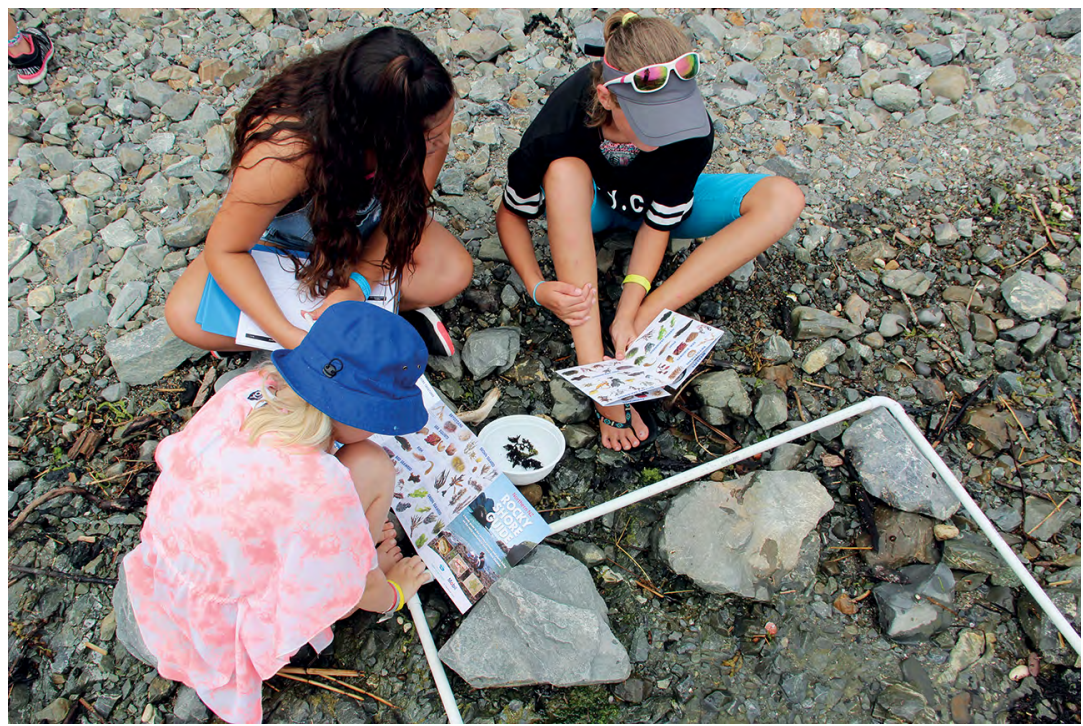

Figure 4.2: Participants in the Marine Metre Squared activity use their guides to identify the organisms they have found within the square metre.

Source: Photo courtesy of Chris Paulin.

The success of ecosanctuaries has reawakened a vision of a NZ free of the many introduced pest species (Sullivan and Molles, 2016) and led to the Predator Free 2050 initiative, supported by government, non-government organisations and philanthropic trusts, and run by the Department of Conservation (Department of Conservation, 2018). This initiative sparked numerous predator-trapping initiatives throughout the country, perhaps epitomised by the group Predator Free NZ (Predator Free NZ, 2018). This grassroots movement in conservation has led to significant government and community engagement, and community-to-community engagement, both in cities and rurally, to help protect, restore and conserve NZ's natural heritage. These successful restoration and pest removal projects (Tanentzap and Lloyd, 2017) have brought New Zealanders face-to-face with the reality of their love of domestic cats and dogs, which contribute to the death of native birds and lizards (Morgan et al., 2009; Farnworth et al., 2010; Gordon et al., 2010; van Heezik et al., 2010; Farnworth et al., 2011; Coughlin and van Heezik, 2014; Aguilar et al., 2015; Harrod et al., 2016; Twardek et al., 2017; Walker et al., 2017).

Participatory science communication initiatives issues also experienced a significant boost through the arrival of the aforementioned Curious Minds funding, which launched a flurry of applications from all over the country. Extra funding was added to the pool at the end of the first year 
to keep up with demand. Since 2015, 114 projects have been funded, including those on the Participatory Science Platforms (New Zealand Government, 2018b). Around 40 per cent of these projects involved studies in conservation, environmental restoration or natural history, including studies on native birds, fish and bats. A similar proportion of projects involved mātauranga, ranging from a program to design Māori digital learning games to one creating marine learning environments through Māori knowledge to inform kaitiakitanga (guardianship) of the oceans and Ahi Pepe Mothnet, a study investigating moth numbers and species throughout the country (New Zealand Government, 2018b).

The goal of Predator Free 2050 (Department of Conservation, 2018) has highlighted the value of NZ's native species, as well as sparking debate on the best way to eradicate introduced predator species. Citizen science initiatives such as NatureWatch (which soon merged with the global iNaturalist (iNaturalist, 2018)), Marine Metre Squared (Fleming et al., 2017), the New Zealand Garden Bird Survey (Spurr, 2012; Liberatore et al., 2018) or Ahi Pepe Mothnet (Manaaki Whenua Landcare Research, 2018) have transformed science engagement across the country, by increasing participation and engagement of young and old. Volunteers are important for the success of many of the environmental projects. When asked why they volunteered, people often said they enjoyed meeting 'like-minded' or 'interesting' new friends. Volunteering was seen as a social activity, bringing better physical and mental health through doing, learning, seeing, contributing and being active outdoors (Fleming, 2017).

\section{Hazards and disasters}

NZ is a country prone to seismic events. In 2010 and 2011 a series of magnitude 6 and 7 earthquakes hit the city of Christchurch in the South Island (Kaiser et al., 2012). The second major shake struck at lunchtime on a working day, causing catastrophic damage to the city, and resulting in 185 deaths (Potter et al., 2015). The government of the day was focused on reporting the events accurately and appeared to be afraid to communicate information that might be wrong or alarm the community (Bryner, 2017). A full analysis of the poor communication of risk and the major players in the suppression of knowledge about the chance of aftershocks can be found in Gorman (2017). The lack of scientific information led to an information void that was filled with a claim by weather forecaster Ken Ring that he had predicted the second earthquake (The National Business Review, 2011). Geologist Dr Mark Quigley, at the time from the University of Canterbury, Christchurch, stepped up to show New Zealanders (and in particular the people 
of Christchurch) what had happened in his own backyard. He emphasised the very complex nature of the seismic event, gave scenarios with ranges of possible outcomes instead of absolutes, wrote about his experience in a deeply personal way (Quigley, 2012) and was honest and open on public media (Quigley, 2018a). Quigley was awarded the 2011 Prime Minister's Prize for Science Media Communication and the NZAS Science Communication Award for his work in communicating earthquake science to the public in the aftermath of these earthquakes (Quigley, 2018b).

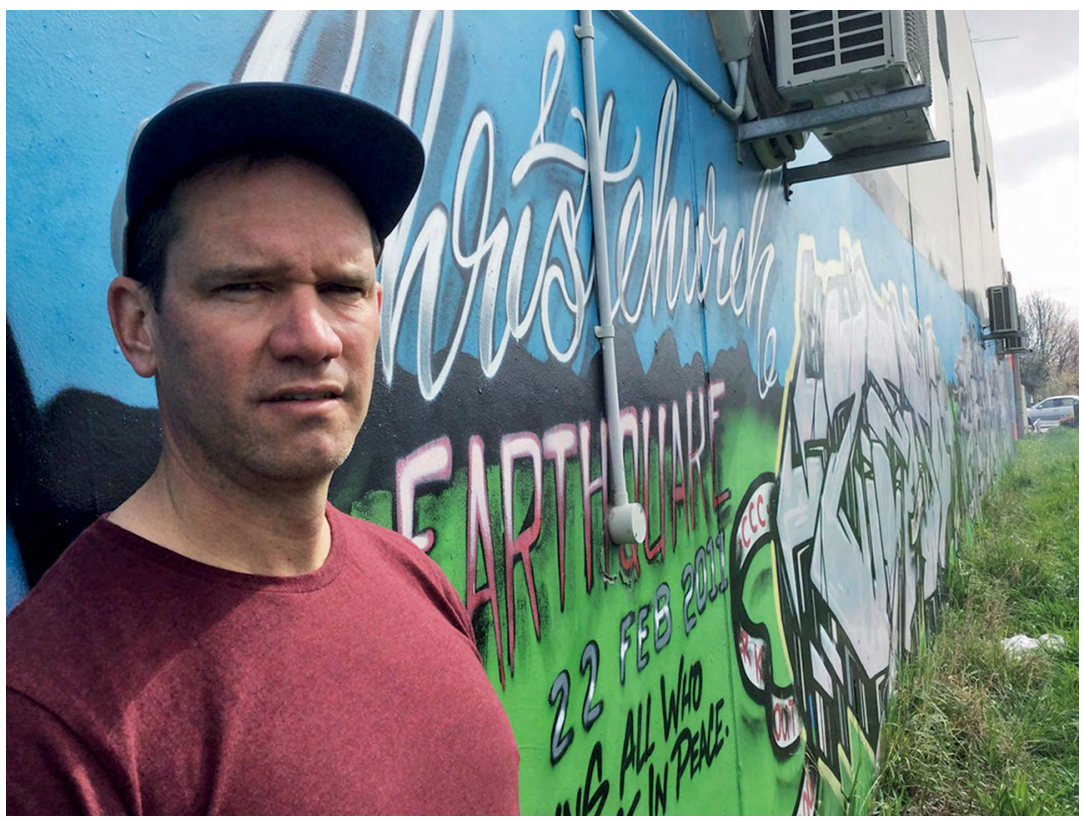

Figure 4.3: Dr Mark Quigley, winner of the Prime Minister's Prize for Science Media Communication in 2011, in Riccarton, near Christchurch in 2015.

Source: Photo courtesy of Candice Egan.

$\mathrm{NZ}$ experienced a second major earthquake event when a magnitude 7.8 earthquake hit Kaikōura and the upper South Island in November 2016, causing landslides and raising parts of the land more than 4 metres (Guo et al., 2018), resulting in considerable damage to roads and property from north Canterbury to Wellington (Bradley et al., 2017; Kaiser et al., 2017). The response of the government and the scientific community was improved from the Christchurch experience, with better public engagement (Blake et al., 2018), including workshops to assess the effectiveness of the recovery response and the lessons learnt (Hatton et al., 2017). The Māori disaster management response received stronger recognition in the media after 
the Kaikōura earthquake, in that media stories highlighted the effectiveness of community-led initiatives as well as the importance of maintaining a unified and well-integrated approach to recovery management.

\title{
7. Seeing science differently: Indigenous science and community engagement
}

\begin{abstract}
Māori concerns about risks to their culture have been consistently marginalized by classing them as 'intangible' or spiritual positions and therefore unable to be evaluated alongside empirical scientific risk assessments. (Hudson et al., 2012)
\end{abstract}

In a succinct video (Goodall, 2016), Dr John Perrott points out that Māori 'belong' (I belong therefore I am), whereas Western scientists are trained to think as individuals (I think therefore I am). In Māori whakapapa (genealogy and cosmology), relationships with the land, flora and fauna are fundamental and all life is valued, as is collaboration and nurturing, all from a position of subjectivity not objectivity (Goodall, 2016). It has taken a long time to reach this open understanding of mätauranga in the NZ science world.

In the late 1980s, in response to the poor health status of Māori, nursing in NZ embarked on a process of improving nurse 'cultural safety' though a process of self-examination and change using Māori nurses. The objective was to challenge trainee nurses to see the world through the eyes of the patients. Cultural safety became a requirement for state examinations in 1992 (Papps and Ramsden, 1996). These changes can be seen as the beginning of 'Western' science engaging with te Ao (the Māori world). Ngā Pae o te Mãramatanga (Horizons of Insight), NZ's Māori Centre of Research Excellence, funded by the Tertiary Education Commission (TEC) and hosted by the University of Auckland, was established in 2002 as one of the foundational Centres of Research Excellence. The centre's current research themes are Whai Rawa (The Māori Economy), Te Tai Ao (The Natural Environment), Mauri Ora (Human Flourishing) and Te Reo me Ngā Tikanga (Māori Language and Protocols).

In 2007, the Vision Mātauranga Policy was launched by the Ministry of Research, Science and Technology (restructured as the Ministry of Business, Industry and Employment in 2012). The Vision Mātauranga policy recognised that while there were many opportunities for Māori communities to make distinctive contributions to research, science and technology, and that many opportunities lay in the innovation potential of Māori knowledge, people and resources, they were not being realised (MBIE, 2018). In 2010, the Minister 
of Science and Innovation approved the integration of Vision Mātauranga across investment priority areas and established the Vision Màtauranga Capability Fund. In 2011, Vision Mātauranga policy was incorporated into the Statements of Core Purpose of the CRIs. CRIs are now required to enable the innovation potential of Mãori knowledge, resources and people as part of their operating principles. Vision Mātauranga thus allowed communities, and the knowledge and potential therein previously disconnected from the science sector, to become fully engaged in science and technology. Vision Mātauranga is now also an integral part of all National Science Challenges, as well as a consideration in all government-led scientific research funding processes (MBIE, 2018).

The arrival of MAI Review (now MAI Journal ${ }^{3}$ ) in 2006 marked another turning point. This refereed academic journal is part of the Capability Building Programme of Ngä Pae o te Màramatanga. MAI Journal contains a wealth of quality material contributing to the body of knowledge about Māori and indigenous development, and help to advance the capabilities of Māori and Indigenous people engaged in research and scholarly training. A growing awareness of mätauranga followed in the science institutions of NZ. A values-based process of cross-cultural dialogue was proposed (Wilcox et al., 2008) and explored (Hudson et al., 2012). Engagement of the Māori community with research on the human brain helped to realise the potential of such research to Māori communities (Bohannon, 2007). Huntington disease research embarked on by Dr Melanie Cheung (Ngāti Rangitihi) for her doctoral project struck a potential barrier: the need to use human brains (from cadavers), considered by Mãori to be tapu or sacred, and not to be touched (Bohannon, 2007). Engagement with tribal elders, who came to realise the importance of such research on the human brain to help Mãori communities, was key in finding a solution to the impasse. Although the elders could not change the brain's tapu status, they created tikanga (ritual protocols), that became part of everyday lab routine. These tikanga enabled Dr Cheung to undertake the work in a culturally safe way (Bohannon, 2007).

This approach pioneered a way for many more researchers, providing a culturally safe working environment for subsequent cohorts of Māori brain researchers. Furthermore, Dr Cheung's work and attention to values such as tapu and the creation of tikanga has provided confidence for Māori who suffer from any brain disease, who likely otherwise would never have come forward. In a similar way, a special issue of the New Zealand Journal of Zoology was devoted to discussion of a seabird harvest in Aotearoa controlled solely

3 MAI Journal is an open-access journal that publishes multidisciplinary peer-reviewed articles that critically analyse and address indigenous and Pacific issues in the context of Aotearoa New Zealand. 
by Māori (muttonbirding). These discussions explored the intersection of mätauranga and science as related ways of guiding sustainable harvest management (Moller, 2009). That special issue prompted the Royal Society of New Zealand to facilitate a 'cross-cultural environmental research and management' Challenges and Progress Forum, with local and international contributions published in the Journal of the Royal Society of New Zealand (Vol. 39, No. 4). Special Mātauranga Māori issues were recently published in the NZ Journal of Marine and Freshwater Research 52(4) 2018, NZ Journal of Ecology 43(3) 2019 and NZ Science Review 75(4) 2019.

Table 4.1: Some differences between mātauranga and science.

\begin{tabular}{|l|l|}
\hline Mātauranga & Science \\
\hline Knowledge as belonging & Knowledge for control and knowing \\
\hline Explicit intrinsic values & Implicit instrumental values \\
\hline Intuition as method & Intuition rarely acknowledged \\
\hline Participatory 'experiencers' of systems & Detached observers of 'systems' \\
\hline Inclusion of facts and values & Facts and values separated \\
\hline Holistic worldview & Nature and culture separate \\
\hline Everything is interconnected & Everything physical is interconnected \\
\hline
\end{tabular}

Source: Hikuroa (2017).

Hikuroa (2017) demonstrated that some mätauranga was and is generated using techniques consistent with the scientific method but differs by being explained according to a Māori world view. Some further differences between mātauranga and science are detailed in Table 3.1. An understanding of the relevance of màtauranga is crucial in encouraging young Māori into careers in science in NZ.

An insight into the gulfbetween màtauranga and the thinking of earlier Western government and industry can be gained from the following description of forestry contamination of an important site (Hikuroa et al., 2011).

Until the early 1960s Rotoitipaku was a shallow lake fed by the spring Te Wai U o Tüwharetoa with active hot springs and sinter terraces on its southern shore, and a prominent feature of Te Kete Poutama ... It was integral for traditional food gathering practices (mahinga kai) of the local Māori residents (tangata whenua), the home for waterborne guardians (kaitiaki) and was the hub for community activity. You would not recognize Te Kete Poutama if you searched for that idyllic scene today. In 1954 the New Zealand Government passed the Tasman Pulp and Paper Company Enabling Act 1954 that essentially gave the Tasman company carte blanche to do everything necessary to construct 
and operate a pulp and paper mill in Kawerau. In effect, the Act removed the tangata whenua's manawhenua and therefore ability to act as kaitiaki ... Over $600,000 \mathrm{~m}^{3}$ of waste containing toxic material has been dumped on the site ... No longer does the lake teem with wildlife (indeed, there is no longer a lake), no longer do the hot springs provide warmth and relief for weary and aching bones, no longer do the ancestors of Ngäti Tüwharetoa ki Kawerau rest in peace, comforted by the constant companionship of their offspring - the mauri of Te Kete Poutama has been significantly compromised and the mana of the tangata whenua significantly impacted. (Hikuroa et al., 2011, pp. 1-2)

In subsequent years, projects were developed by Māori researchers to reflect community concern at the framing of mätauranga as relevant only in the traditional context and not in the modern science world (Hudson et al., 2012). Thus, Māori engaged the science community to broaden perceptions and used mätauranga to inspire collaborations that might lead to new avenues of scientific exploration. Some examples include the Kaitiaki Geothermal Development Model (e.g. Pryor, 2010), Te Awaroa (Hikuroa et al., 2018) and Te Ao Mārama - Centre for Fundamental Inquiry research collaboration, University of Auckland.

The development of the National Science Challenges was seen by some to marginalise participation by Māori researchers, in part through constructing 'Mãori' and 'science' as separate, yet simultaneously recognising culturally distinctive forms of Mãori knowledge. Others saw greater opportunity for mätauranga by the emphasis on Vision Mātauranga. By advocating for the validity of their mätauranga, Mãori health researchers contested Pākehā values and priorities, reasserted the validity of mätauranga, and began the process of changing the production of knowledge in NZ across the board (Prussing and Newbury, 2016).

Māori advocacy against the values and priorities held by the majority of scientists and science institutions in NZ challenged trends to undermine collective rights and undercut support for culturally diverse worldviews by pointing out the ways in which market-driven priorities produce and sustain environmental, social and health inequities. One basis for the advocacy stems from the inclusion of values in mätauranga. By 2016, Sciblogs, the blog site of NZ's Science Media Centre, had recognised and defined the values of mätauranga (Goodall, 2016). Ocean Ripeka Mercier and her co-writers were discussing the potential marriage of Western science and mätauranga and proclaiming the 'veritableness' of Mãori science (Macfarlane, 2016, 2017). Unsurprisingly, the marriage does not always involve smooth sailingthere is always potential for miscommunications between parties coming to a problem or project with different world views (Longnecker and Scott, 2018). 


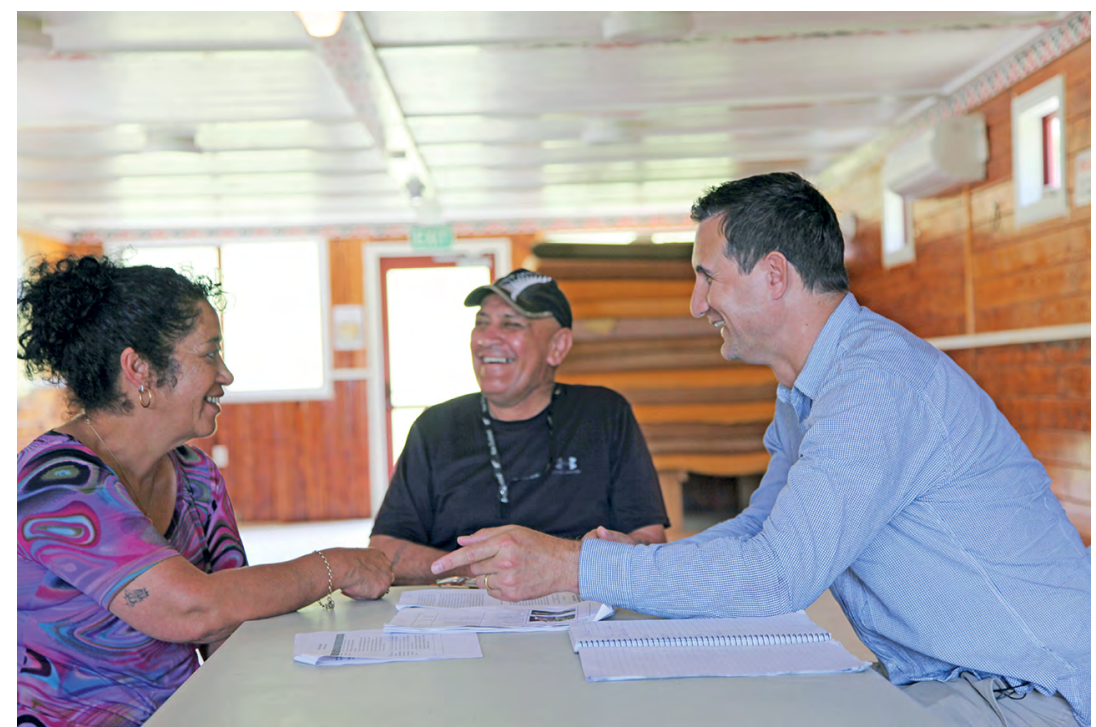

Figure 4.4: Researchers discussing the mauri of Te Kete Poutama within Waitaha Ariki Kore, ancestral house of Tohia o te Rangi marae, Kawerau. Left to right: Colleen Skerrett-White, Tomairangi Fox and Dan Hikuroa, November 2011.

Source: Photo courtesy of Ngā Pae o te Māramatanga.

Nonetheless, in recent years we have seen this marriage in action. Indigenous communities are increasingly taking the lead in river restoration, using the process as an opportunity to re-engage deeply with their rivers, while revealing sociocultural and political dimensions of restoration under-reported in ecological and social science literatures (Fox et al., 2017). Mātauranga solutions to some of NZ's toughest problems, including kauri dieback disease (Chetham and Shortland, 2013), are increasingly being sought (Williams, 2017; Darragh, 2018; Harrison, 2018; Hurihanganui, 2018; New Zealand's Biological Heritage, 2018; Pitama et al., 2018).

\section{Learning to communicate science}

One approach to improve understanding and practice of science communication, as well as fostering a culture with greater critical feedback about contemporary science communication, is to provide education and training to aspiring communicators and scientists. Early academic courses in communication studies, including the communication of science, were present in NZ from the late 1970s, but training mainly focused on science journalism until the end of 20th century (Fleming and Star, 2017). 
Early in the 21st century, public debate about science was exemplified by the New Zealand Royal Commission on Genetic Modification (RCGM), which engaged thousands of ordinary New Zealanders with developments in biotechnology (Eichelbaum et al., 2001). Ten thousand public submissions were made to the commission and over 90 per cent of these were strongly against genetic modification, although knowledge of the technology was limited. Many submitters were concerned by the control of science and scientists by large corporations such as Monsanto rather than the biotechnology itself (Fleming, 2003). The RCGM showed the government of the day that NZ needed to move on from the deficit model of science communication and to include New Zealanders in difficult scientific decisions (Fleming, 2003). As the Chair of the RCGM, Sir Thomas Eichelbaum, said: 'Few minds may have been changed in the process but everyone emerged better informed and more willing to listen to each other' (Fleming, 2003).

The AC Nielsen survey conducted by the RCGM showed the majority of New Zealanders were interested in and engaged with aspects of science and technology, especially where personal or societal benefits were most obvious (such as health). Most New Zealanders surveyed in 2002 held strongly realistic views of science, with a significant proportion appearing to hold the view that 'seeing was believing' and not inclined to take scientific claims on trust, possibly because of a lack of understanding about how scientific evidence was generated (Hipkins et al., 2002). There is evidence that knowledge and understanding of GM has changed since 2002 and that a large majority of New Zealanders would now accept at least some forms of GM (Hope, 2014).

It took until 2008 for the first tertiary training centre, the University of Otago's Centre for Science Communication (University of Otago, 2018), to be established in NZ. This successful centre has grown over the past decade to be one of the biggest centres for postgraduate training in science communication in the world. Science communication is taught at four other universities in $\mathrm{NZ}$ and is a key focus in undergraduate and postgraduate programs established in 2013 by the Centre for Science in Society at Victoria University of Wellington.

An increasing number of research degrees are being awarded in science communication in NZ. While the first PhD in science communication was awarded as recently as 2015 by the University of Otago (Cade, 2015), at time of writing its Centre for Science Communication has $14 \mathrm{PhD}$ students and 60 postgraduate science communication coursework and MSciComm students enrolled. Government-funded research centres are increasingly engaged with science communication research. For example, in 2018, Te Pūnaha Matatini (a Centre of Research Excellence) provided a fully funded $\mathrm{PhD}$ scholarship to explore the process of science communication in NZ. 
NZ's first science communication conference in 2001 was run by the Royal Society of New Zealand Te Apārangi, which has played a key role in colonial and post-colonial NZ science (Fleming and Star, 2017). In 2004, agricultural journalist Peter Burke formed the national Science Communicators' Association of New Zealand (SCANZ). He had attended an international science communication conference (PCST) in 2002 in Cape Town, South Africa, and noted the value of organisations for science communicators that existed in many countries around the world. The growing number of science communicators, along with a decreasing number of specialised science journalists employed by national newspapers (Hendy, 2016), has seen SCANZ grow substantially, with the annual conference becoming a popular place for presentation of science communication research (SCANZ, 2018). In 2018, the international biennial PCST conference was hosted in Dunedin, $\mathrm{NZ}$, bringing together colleagues from around to the world for this important opportunity to share knowledge and practices.

Today, the value of science communication for NZ society is recognised not only through the NZAS's Science Communication Award launched in 1990 (now the Cranwell Medal), but also prizes awarded by the Royal Society Te Apārangi (Callaghan Medal, launched 2011), the Science Communicators' Association of New Zealand (launched 2015), and the prestigious Prime Minister's Science Communication Prize (launched 2009) worth NZ\$100,000.

\section{Conclusions}

In NZ, the beginning of the 21 st century has seen an increase in the collaboration of mätauranga with Western science at a time of heightened awareness about environmental issues. Māori researchers have pushed to widen the perspectives of the scientific community, using dialogue initially, but more and more by engaging communities with mätauranga. Mātauranga and new dialogic approaches have complemented and added depth to established practices in science communication, such as conferences, science festivals and social media. Māori have taken science communication in Aotearoa New Zealand in new directions, with an increasing emphasis on the inherent values of the science being communicated.

There have also been significant increases in training opportunities, formal education, funding and jobs in science communication over the past decade. Linked to this has been a substantial rise in the number and diversity of participatory science programs in NZ, a good proportion concerning environmental protection and restoration (Peters et al., 2016), assisted by the establishment of a source of funding (New Zealand Government, 2018b). 
As a result, NZ's communities are engaging more with science, hopefully creating more science-literate publics and a more public-literate and bicultural science community.

\section{Acknowledgement}

The authors gratefully acknowledge and thank Associate Professor Rebecca Priestley (Victoria University of New Zealand) for her advice on this chapter.

\section{References}

Aguilar, G. D., Farnworth, M. J. and Winder, L. (2015). Mapping the stray domestic cat (Felis catus) population in New Zealand: Species distribution modelling with a climate change scenario and implications for protected areas. Applied Geography, 63, 146-54. doi.org/10.1016/j.apgeog.2015.06.019.

Ashwell, D. J. (2016). The challenges of science journalism: The perspectives of scientists, science communication advisors and journalists from New Zealand. Public Understanding of Science, 25(3), 379-93. doi.org/10.1177/09636625 14556144.

Bess, R. (2011). New Zealand's Treaty of Waitangi and the doctrine of discovery: Implications for the foreshore and seabed. Marine Policy, 35(1), 85-94. doi.org/ 10.1016/j.marpol.2010.08.007.

Bewsell, D., Bigsby, H. and Cullen, R. (2012). Using involvement to understand individual responses to an issue: The case of New Zealand biosecurity. New Zealand Journal of Agricultural Research, 55(1), 73-88. doi.org/10.1080/ 00288233.2011 .647354 .

Blake, D., Johnston, D., Leonard, G., McLaren, L. and Becker, J. (2018). A Citizen Science Initiative to Understand Community Response to the Kaikoura Earthquake and Tsunami Warning in Petone and Eastbourne, Wellington, Aotearoa/New Zealand. Bulletin of the Seismological Society of America, 108(3B), 1807-17. doi.org/10.1785/0120170292.

Bohannon, J. (2007). Michael Walker - A home for Maori science. Science, 318(5852), 907. doi.org/10.1126/science.318.5852.907.

Bradley, B. A., Razafindrakoto, H. N. T. and Polak, V. (2017). Ground-Motion Observations from the 14 November 2016 M-w 7.8 Kaikoura, New Zealand, Earthquake and Insights from Broadband Simulations. Seismological Research Letters, 88(3), 740-56. doi.org/10.1785/0220160225.

Broughton, D. and McBreen, K. (2015). Mātauranga Māori, tino rangatiratanga and the future of New Zealand Science. Journal of the Royal Society of New Zealand, 45(2), 83-88. doi.org/10.1080/03036758.2015.1011171. 
Bryner, V. (2017). Communicating the sciences of disaster risk reduction: media stories surrounding the Canterbury earthquakes of 2010-2011 (unpublished $\mathrm{PhD}$ thesis). University of Otago, Dunedin, New Zealand.

Bucchi, M. (1998). The future of science has begun. The communication of science to the public: Science and the media. Proceedings of the Fifth International Conference. Public Understanding of Science, 7(4), 349-50.

Bucchi, M. (2008). Of deficits, deviations and dialogues: Theories of public communication of science. In M. Bucchi and B. Trench (eds), Handbook of Public Communication of Science and Technology. Abingdon, UK and New York, USA: Routledge.

Cade, O. J. (2015). Communicating science through poetry from 1780 to the present (PhD thesis). University of Otago, Dunedin, New Zealand.

Campbell-Hunt, D. (2002). Developing a Sanctuary: The Karori Experience. Wellington: Victoria Link Ltd.

Campbell-Hunt, D. and Campbell-Hunt, C. (2013). Ecosanctuaries: Communities building a future for New Zealand's threatened ecologies. Dunedin: Otago University Press.

Chetham, J. and Shortland, T. (2013). Kauri cultural health indicators - Monitoring. Auckland: Kauri Dieback Joint Agency Response, Tangata Whenua Roopu.

Collins, P. M. D. and Bodmer, W. F. (1986). The Public Understanding of Science. Studies in Science Education, 13(1), 96-104.

Coughlin, C. E. and van Heezik, Y. (2014). Weighed down by science: Do collarmounted devices affect domestic cat behaviour and movement? Wildlife Research, 41(7), 606-14. doi.org/10.1071/wr14160.

Cronin, K. (2008). The privatization of public talk: A New Zealand case study on the use of dialogue for civic engagement in biotechnology governance. New Genetics and Society, 27(3), 285-99. doi.org/10.1080/14636770802326950.

Csiszar, A. (2017). How lives became lists and scientific papers became data: Cataloguing authorship during the nineteenth century. British Journal for the History of Science, 50(1), 23-60. doi.org/10.1017/s0007087417000012.

Darragh, T. A. (2018). Finding New Zealand's Scientific Heritage: From Mātauranga Māori to Augustus Hamilton. Journal of the Royal Society of New Zealand, 29(2), 207. doi.org/10.1080/03036758.2016.1265995.

Davies, A. R. (2009). Clean and green? A governance analysis of waste management in New Zealand. Journal of Environmental Planning and Management, 52(2), 157-76. doi.org/10.1080/09640560802666503. 
Department of Conservation. (2018). Predator Free 2050. Wellington: Department of Conservation. Retrieved from www.doc.govt.nz/nature/pests-and-threats/ predator-free-2050/.

Douglas, G. L. (1988). History of science and technology resources at the Linnean Society of London. British Journal for the History of Science, 21(71), 489-93.

Dowding, J. E. and Murphy, E. C. (2001). The impact of predation by introduced mammals on endemic shorebirds in New Zealand: A conservation perspective. Biological Conservation, 99(1), 47-64. doi.org/10.1016/s0006-3207(00)00187-7.

Eichelbaum, T., Allan, J., Fleming, J. and Randerson, R. (2001). Report of the Royal Commission on Genetic Modification. Wellington: Department of Internal Affairs, New Zealand.

Farnworth, M. J., Campbell, J. and Adams, N. J. (2010). Public awareness in New Zealand of animal welfare legislation relating to cats. New Zealand Veterinary Journal, 58(4), 213-17. doi.org/10.1080/00480169.2010.68624.

Farnworth, M. J., Campbell, J. and Adams, N. J. (2011). What's in a Name? Perceptions of Stray and Feral Cat Welfare and Control in Aotearoa, New Zealand. Journal of Applied Animal Welfare Science, 14(1), 59-74. doi.org/10.1080/ 10888705.2011 .527604 .

Fiedler, A. K., Landis, D. A. and Wratten, S. D. (2008). Maximizing ecosystem services from conservation biological control: The role of habitat management. Biological Control, 45(2), 254-71. doi.org/10.1016/j.biocontrol.2007.12.009.

Fleming, C. A. (1987). Science, Settlers and Scholars. Wellington: The Royal Society of New Zealand.

Fleming, J. S. (2003). Inform, educate or influence? New Zealand's experience of the debate on genetic modification. The Round Table: The Commonwealth Journal of International Affairs, 371, 487-99. doi.org/10.1080/0035853032000126174.

Fleming, J. S. (2017). Why do we do it? Forest \& Bird Magazine, Te Reo o te Taiao, $364,28-9$.

Fleming, J. S., Broni, B., Copeland, S., Hunt, D. and Newburn, R. (2017). Thirty years of science outreach at the University of Otago. New Zealand Science Review, $74(1), 10-13$.

Fleming, J. S. and Star, J. (2017). The emergence of science communication in Aotearoa New Zealand. Journal of Science Communication, 16(3), A02. doi.org/ $10.22323 / 2.16030202$.

Fox, C. A., Reo, N. J., Turner, D. A., Cook, J., Dituri, F., Fessell, B., Jenkins, J., Johnson, A., Rakena, T. M., Riley, C., Turner, A., Williams, J. and Wilson, M. (2017). 'The river is us; the river is in our veins': Re-defining river restoration in three indigenous communities. Sustainability Science, 12(4), 521-33. doi.org/ 10.1007/s11625-016-0421-1. 
France, B., Mora, H. A. and Bay, J. L. (2012). Changing Perspectives: Exploring a pedagogy to examine other perspectives about stem cell research. International Journal of Science Education, 34(5), 803-24. doi.org/10.1080/09500693.2011. 630427.

Galbraith, M., Bollard-Breen, B. and Towns, D. R. (2016). The CommunityConservation Conundrum: Is Citizen Science the Answer? Land, 5(4). doi.org/ $10.3390 /$ land 5040037 .

Galbreath, Ross (1998). DSIR: Making Science Work for New Zealand: Themes from the History of the Department of Scientific and Industrial Research, 1926-1992. Wellington: Victoria University Press.

Gascoigne, T., Cheng, D., Claessens, M., Metcalfe, J., Schiele B. and Shi, S. (2010). Is science communication its own field? , Journal of Science Communication, 9(3), C04. doi.org/10.22323/2.09030304.

Gifford, R. M., Campbell, B. D. and Howden, S. M. (1996). Options for adapting agriculture to climate change: Australian and New Zealand examples. In W. J. Bouma, G. I. Pearman and M. R. Manning (eds), Greenhouse: Coping with climate change (pp. 399-416). Melbourne: CSIRO Publishing.

Gluckman, P. (2013). Report of the National Science Challenges Panel. Ministry of Science and Innovation. Wellington: New Zealand Government.

Goodall, L. (2016). What is Mātauranga Māori? SciBlogs. Retrieved from sciblogs. co.nz/matau-taiao/2016/02/26/what-is-matauranga-maori/.

Gordon, J. K., Matthaei, C. and van Heezik, Y. (2010). Belled collars reduce catch of domestic cats in New Zealand by half. Wildlife Research, 37(5), 372-78. doi.org/ 10.1071/wr09127.

Gorman, P. (2017). Portacom City. Reporting on the Christchurch and Kaikoura earthquakes. Wellington: Bridget Williams Books.

Green, W. and Rohan, M. (2012). Opposition to aerial 1080 poisoning for control of invasive mammals in New Zealand: risk perceptions and agency responses. Journal of the Royal Society of New Zealand, 42(3), 185-213. doi.org/10.1080/ 03036758.2011 .556130 .

Gregory, G. (2017). Service to science: History of the New Zealand Association of Scientists. Journal of the Royal Society of New Zealand, 47(2), 175-80. doi.org/ 10.1080/03036758.2017.1291435.

Gregory, M. R. (1978). Accumulation and distribution of virgin plastic granules on New Zealand beaches. New Zealand Journal of Marine and Freshwater Research, 12(4), 399-414.

Griffin, P. (2014). When scientists don't speak out - gag orders and funding fears revealed. SciBlogs. Retrieved from sciblogs.co.nz/griffins-gadgets/2014/11/03/ when-scientists-dont-speak-out-gag-orders-and-funding-fears-revealed/. 
Guo, P., Han, Z., Ran, H., Luo, J.-H., Wu, G. and Yuan, R.-M. (2018). Co-seismic surface rupture of Papatea fault and reactivation mechanism of the Clarence landslide during the 2016 Mw7.8 Kaikoura earthquake, New Zealand. Bulletin of Engineering Geology and the Environment, 5. doi.org/10.1007/s10064-018-1338-y.

Harrison, R. (2018). Potential whakapapa Māori solution for kāuri dieback outbreak. Māori Television. Retrieved from www.teaomaori.news/potential-whakapapamaori-solution-kauri-dieback-outbreak.

Harrod, M., Keown, A. J. and Farnworth, M. J. (2016). Use and perception of collars for companion cats in New Zealand. New Zealand Veterinary Journal, 64(2), 12124. doi.org/10.1080/00480169.2015.1110064.

Hatton, T., Kipp, B., Brown, C. and Seville, E. (2017). Kaikoura earthquake social science research workshop report. QuakeCoRE publication number 0177.

Hendy, S. (2016). Silencing Science: Science that is not heard is not science at all. Wellington: Bridget Williams Books.

Hikuroa, D. (2017). Mātauranga Māori - the ūkaipō of knowledge in New Zealand. Journal of the Royal Society of New Zealand, 47(1), 5-10. doi.org/ 10.1080/03036758.2016.1252407.

Hikuroa, D. (2018). Te Awaroa: Voice of the river. Te Pūnaha Matatini. Retrieved from www.tepunahamatatini.ac.nz/2017/09/11/wainz2/.

Hikuroa, D., Slade, A. and Gravley, D. (2011). Implementing Māori indigenous knowledge (mātauranga) in a scientific paradigm: Restoring the mauri to Te Kete Poutama. MAI Review, 3. Retrieved from www.review.mai.ac.nz/mrindex/MR/ article/viewArticle/433.html.

Hipkins, R., Stockwell, W., Bolstad, R. and Baker, R. (2002). Commonsense, trust and science: How patterns of beliefs and attitudes to science pose challenges for effective communication. Ministry of Research, Science and Technology. Wellington: New Zealand Government.

Hope, K. M. (2014). Socioscientific issues: A survey of New Zealanders' attitudes towards GE (unpublished MSciComm thesis). University of Otago, Dunedin, New Zealand.

Hudson, M., Roberts, M., Smith, L., Tiakiwai, S. J. and Hemi, M. (2012). The art of dialogue with indigenous communities in the new biotechnology world. New Genetics and Society, 31(1), 11-24. doi.org/10.1080/14636778.2011.597979.

Hudson, M. L. and Russell, K. (2009). The Treaty of Waitangi and research ethics in Aotearoa. Journal of Bioethical Inquiry, 6(1), 61-8. doi.org/10.1007/s11673008-9127-0.

Hurihanganui, T. A. (2018). Kauri dieback fight: Scientist warns of Mãori exclusion. Radio New Zealand. Retrieved from www.rnz.co.nz/news/te-manukorihi/365776/kauri-dieback-fight-scientist-warns-of-maori-exclusion. 
iNaturalist. (2018). iNaturalist NZ - Mãtaki Taiao. Wellington. Retrieved from inaturalist.nz/.

Joy, M. K., Foote, K. J., McNie, P. and Piria, M. (2018). Decline in New Zealand's freshwater fish fauna: Effect of land use. Marine and Freshwater Research, 70(1) 114-24. doi.org/10.1071/mf18028.

Kaiser, A., Balfour, N., Fry, B., Holden, C., Litchfield, N., Gerstenberger, M., D’Anastasio, E., Horspool, N., McVerry, G., Ristau, J., Bannister, S., Christophersen, A., Clark, K., Power, W., Rhoades, D., Massey, C., Hamling, I., Wallace, L., Mountjoy, J., Kaneko, Y., Benites, R., Van Houtte, C., Dellow, S., Wotherspoon, L., Elwood, K. and Gledhill, K. (2017). The 2016 Kaikoura, New Zealand, Earthquake: Preliminary Seismological Report. Seismological Research Letters, 88(3), 727-39. doi.org/10.1785/0220170018.

Kaiser, A., Holden, C., Beavan, J., Beetham, D., Benites, R., Celentano, A., Collett, D., Cousins, J., Cubrinovski, M., Dellow, G., Denys, P., Fielding, E., Fry, B., Gerstenberger, M., Langridge, R., Massey, C., Motagh, M., Pondard, N., McVerry, G., Ristau, J., Stirling, M., Thomas, J., Uma, S. R. and Zhao, J. (2012). The Mw 6.2 Christchurch earthquake of February 2011: Preliminary report. New Zealand Journal of Geology and Geophysics, 55(1), 67-90. doi.org/10.1080/ 00288306.2011 .641182 .

Klein, A. (2018). New Zealand becomes the latest country to ban plastic bags. New Scientist, 239(3191), 5. doi.org/10.1016/s0262-4079(18)31453-2.

Lambert, D. M., Shepherd, L. D., Huynen, L., Beans-Picôn, G., Walter, G. H. and Millar, C. D. (2009). The molecular ecology of the extinct New Zealand huia. PLoS One, 4(11), e8019. doi.org/10.1371/journal.pone.0008019.

Leitch, S., Motion, J., Merlot, E. and Davenport, S. (2014). The fall of research and rise of innovation: Changes in New Zealand science policy discourse. Science and Public Policy, 41(1), 119-23. doi.org/10.1093/scipol/sct042.

Levitin, D. (2015). 'Made Up from Many Experimental Notions': The Society of Apothecaries, Medical Humanism, and the Rhetoric of Experience in 1630s London. Journal of the History of Medicine and Allied Sciences, 70(4), 549-87. doi.org/10.1093/jhmas/jru027.

Liberatore, A., Bowkett, E., MacLeod, C., Spurr, E. and Longnecker, N. (2018). Social Media as a Platform a Citizen Science Community of Practice. Citizen Science: Theory and Practice, 3(1), 3. doi.org/10.5334/cstp.108.

Longnecker, N. (2016a). An integrated model of science communication: More than providing evidence. Journal of Science Communication, 15(5). doi.org/10.22323/ 2.15050401 .

Longnecker, N. (2016b). Book Review: Silencing Science by Shaun Hendy. Journal of the Royal Society of New Zealand, 46(3-4), 238-9. doi.org/10.1080/ 03036758.2016.1230553. 
Longnecker, N. and Scott, C. (2018). Challenges of cross-cultural communication in production of a collaborative exhibition: Wai ora, Mauri ora. Journal of Science Communication, 17(04), C05. doi.org/10.22323/2.17040305.

Macfarlane, A. (2016). Enhancing Matauranga Maori and Global Indigenous Knowledge. New Zealand Journal of Educational Studies, 51(1), 129-32.

Macfarlane, A. (2017). Enhancing Matauranga Maori and Global Indigenous Knowledge. New Zealand Journal of Educational Studies, 52(1), 205.

Manaaki Whenua Landcare Research. (2018). Ahi Pepe: Mothnet. Dunedin: Manaaki Whenua Landcare Research. Retrieved from www.landcareresearch. co.nz/information-for/citizen-science/mothnet.

Mark, A. (2001). 'Integrating conservation with hydro-electric development of Lakes Manapouri and Te Anau, New Zealand: an exercise in complexity'. Complexity International, 8(1), 1-19.

Mark, A. F. (2015). Standing My Ground: A voice for nature conservation. Dunedin: Otago University Press.

Mark, A. F. and Johnson, P. N. (1985). Ecologically derived guidelines for managing two New Zealand lakes. Environmental Management, 9(4), 355-64. doi.org/ 10.1007/bf01867306.

Martin, J. E. (2017). Reflections on the history of the Royal Society Te Apārangi. New Zealand Journal of Social Sciences, 12(2), 277-88. doi.org/10.1080/ $1177083 x .2017 .1391301$.

MBIE. (2013). National Science Challenges: Key messages regarding challenge principles. MBIE-MAKO-10986337, Ministry of Business, Innovation and Employment. Wellington: New Zealand Government.

MBIE. (2016). Our Science Board. Ministry of Business, Innovation and Employment. Wellington: New Zealand Government. Retrieved from www.mbie.govt.nz/ about/who-we-are/our-external-boards/our-science-board/.

MBIE. (2018). Vision Mãtauranga. Ministry of Business, Innovation and Employment. Wellington: New Zealand Government. Retrieved from www.mbie.govt.nz/ info-services/science-innovation/agencies-policies-budget-initiatives/visionmatauranga-policy.

McCarthy, D. and Rands, M. (2013). Learned societies: A bridge between research, policy making and funding. Studies in Higher Education, 38(3), 470-83. doi.org/ 10.1080/03075079.2013.773216.

McWethy, D. B., Whitlock, C., Wilmshurst, J. M., McGlone, M. S. and Li, X. (2009). Rapid deforestation of South Islands, New Zealands, by early Polynesian fires. Holocene, 19(6), 883-97. doi.org/10.1177/0959683609336563. 
McWethy, D. B., Wilmshurst, J. M., Whitlock, C., Wood, J. R. and McGlone, M. S. (2014). A High-Resolution Chronology of Rapid Forest Transitions following Polynesian Arrival in New Zealand. PLoS One, 9(11). doi.org/10.1371/journal. pone. 0111328 .

Ministry for the Environment. (2008). Preparing for Climate Change: A guide for local government in New Zealand. Wellington: Ministry for the Environment.

Mohi, J. H. and Roberts, W. D. (2009). Delivering a strategy for working with Māori, and developing responsiveness to an increasingly multicultural population: A perspective from the National Library of New Zealand. IFLA Journal, 35(1), 48-58 and 79-82. doi.org/10.1177/0340035208102037.

Moller, H. (2009). Mātauranga Māori, science and seabirds in New Zealand. New Zealand Journal of Zoology, 36(3), 203-10. doi.org/10.1080/0301422 0909510151.

Morgan, S. A., Hansen, C. M., Ross, J. G., Hickling, G. J., Ogilvie, S. C. and Paterson, A. M. (2009). Urban cat (Felis catus) movement and predation activity associated with a wetland reserve in New Zealand. Wildlife Research, 36(7), 574-80. doi.org/ $10.1071 / \mathrm{wr} 09023$.

Muellner, P., Hodges, D., Ahlstrom, C., Newman, M., Davidson, R., Pfeiffer, D., Marshall, J. and Morley, C. (2018). Creating a framework for the prioritization of biosecurity risks to the New Zealand dairy industry. Transboundary and Emerging Diseases, 65(4), 1067-77. doi.org/10.1111/tbed.12848.

Munshi, D., Kurian, P. A., Morrison, T. and Morrison, S. L. (2016). Redesigning the architecture of policy-making: Engaging with Māori on nanotechnology in New Zealand. Public Understanding of Science, 25(3), 287-302. doi.org/ 10.1177/0963662514548629.

New Zealand Government. (2018a). Origins of Curious Minds. Wellington: Ministry of Business, Innovation and Employment. Retrieved from www.curiousminds.nz/ about/history/.

New Zealand Government. (2018b). Projects funded by Curious Minds. Wellington: Ministry of Business, Innovation and Employment. Retrieved from www.curious minds.nz/projects/.

New Zealand's Biological Heritage. (2018). Stopping kauri dieback in its tracks. National Science Challenges. Retrieved from bioheritage.nz/research/stoppingkauri-dieback/.

Nielsen Research. (2018). Report on Public Engagement with Science \& Technology. Wellington: Ministry of Business, Innovation and Employment.

Norbury, G. and Jones, C. (2015). Pests controlling pests: does predator control lead to greater European rabbit abundance in Australasia? Mammal Review, 45(2), 79-87. doi.org/10.1111/mam.12034. 
Office of the Prime Minister's Chief Science Advisor (OPMCSA). (2018). Our Office - Prime Minister's Chief Science Advisor. Wellington. Retrieved from www. pmcsa.ac.nz/who-we-are/our-office/.

Orange, C. (2011). The Treaty of Waitangi. Wellington, NZ: Bridget Williams Books.

Orchiston, C. (2010). Tourism and seismic risk: Perceptions, preparedness and resilience in the zone of the Alpine Fault, Southern Alps, New Zealand (PhD thesis). University of Otago, Dunedin, New Zealand.

Papps, E. and Ramsden, I. (1996). Cultural safety in nursing: The New Zealand experience. International Journal for Quality in Health Care, 8(5), 491-97. doi.org/ 10.1093/intqhe/8.5.491.

Peters, M. A., Eames, C. and Hamilton, D. (2015). The use and value of citizen science data in New Zealand. Journal of the Royal Society of New Zealand, 45(3), 151-60. doi.org/10.1080/03036758.2015.1051549.

Peters, M. A., Hamilton, D., Eames, C., Innes, J. and Mason, N. W. H. (2016). The current state of community-based environmental monitoring in New Zealand. New Zealand Journal of Ecology, 40(3), 279-88. doi.org/10.20417/nzjecol.40.37.

Pieczka, M. and Escobar, O. (2013). Dialogue and science: Innovation in policymaking and the discourse of public engagement in the UK. Science and Public Policy, 40(1), 113-26. doi.org/10.1093/scipol/scs073.

Pitama, S. G., Palmer, S. C., Huria, T., Lacey, C. and Wilkinson, T. (2018). Implementation and impact of indigenous health curricula: a systematic review. Medical Education, 52(9), 898-909. doi.org/10.1111/medu.13613.

Potter, S. H., Becker, J. S., Johnston, D. M. and Rossiter, K. P. (2015). An overview of the impacts of the 2010-2011 Canterbury earthquakes. International Journal of Disaster Risk Reduction, 14, 6-14. doi.org/10.1016/j.ijdrr.2015.01.014.

Predator Free NZ. (2018). Predator Free NZ. Retrieved from predatorfreenz.org/.

Priestley, R. (ed.). (2008). The Awa Book of New Zealand Science. Wellington, NZ: Awa Press.

Priestley, R. (2010). A Survey of the History of Science in New Zealand, 1769-1992. History Compass, 8(6), 474-90. doi.org/10.1111/j.1478-0542.2010.00684.x.

Prussing, E. and Newbury, E. (2016). Neoliberalism and indigenous knowledge: Maori health research and the cultural politics of New Zealand's 'National Science Challenges'. Social Science \& Medicine, 150, 57-66. doi.org/10.1016/ j.socscimed.2015.12.012.

Pryor, R. (2010). A kaitiaki approach to geothermal development: Encompassing the Mãori worldview in New Zealand's growing renewable energy industry. Retrieved from frontiersabroad.com/wp-content/uploads/2012/09/RebeccaPryor.pdf. 
Quigley, M. C. (2012). Mark Quigley's long, cold year. The Press. Retrieved from www.stuff.co.nz/the-press/news/christchurch-earthquake-2011/12-51/the-earth/ 6413953/Mark-Quigleys-long-cold-year.

Quigley, M. C. (2018a). Dr Quigs. Retrieved from www.drquigs.com/.

Quigley, M. C. (2018b). About. Retrieved from www.drquigs.com/?page_id=13.

Roper, J., Ganesh, S. and Zorn, T. E. (2016). Doubt, Delay, and Discourse: Skeptics' Strategies to Politicize Climate Change. Science Communication, 38(6), 776-99. doi.org/10.1177/1075547016677043.

Royal Society of New Zealand. (2016). Climate change implications for New Zealand (Online). Wellington, New Zealand: Royal Society of New Zealand. doi.org/ 10.1080/03036758.2018.1476389.

Ruffino, L., Zarzoso-Lacoste, D. and Vidal, E. (2015). Assessment of invasive rodent impacts on island avifauna: methods, limitations and the way forward. Wildlife Research, 42(2), 185-95. doi.org/10.1071/wr15047.

Salmon, R. A. and Priestley, R. K. (2015). A future for public engagement with science in New Zealand. Journal of the Royal Society of New Zealand, 45(2), 101-7. doi.org/10.1080/03036758.2015.1023320.

Salmon, R., Priestley, R., Fontana, M., and Milfont, T. (2017). Climate Change Communication in New Zealand. Oxford Research Encyclopedia of Climate Science. doi.org/10.1093/acrefore/9780190228620.013.475.

SCANZ. (2018). Science Communicators' Association of New Zealand. Auckland. Retrieved from www.scanz.co.nz/.

Seersholm, F. V., Cole, T. L., Grealy, A., Rawlence, N. J., Greig, K., Knapp, M., Stat, M., Hansen, A. J., Easton, L. J., Shepherd, L., Tennyson, A. J. D., Scofield, R. P., Walter, R. and Bunce, M. (2018). Subsistence practices, past biodiversity, and anthropogenic impacts revealed by New Zealand-wide ancient DNA survey. Proceedings of the National Academy of Sciences of the United States of America, 115(30), 7771-6. doi.org/10.1073/pnas.1803573115.

Smallman, M. (2016). Public Understanding of Science in turbulent times III: Deficit to dialogue, champions to critics. Public Understanding of Science, 25(2), 186-97. doi.org/10.1177/0963662514549141.

Spurr, E. B. (2012). New Zealand Garden Bird Survey - analysis of the first four years. New Zealand Journal of Ecology. 36(3), 1-13.

St Clair, J. J. H. (2011). The impacts of invasive rodents on island invertebrates. Biological Conservation, 144(1), 68-81. doi.org/10.1016/j.biocon.2010.10.006. 
Storey, R. G. and Wright-Stow, A. (2017). Community-based monitoring of New Zealand stream macroinvertebrates: agreement between volunteer and professional assessments and performance of volunteer indices. New Zealand Journal of Marine and Freshwater Research, 51(1), 60-77. doi.org/10.1080/00288330.2016.1266674.

Sullivan, J. J. and Molles, L. E. (2016). Biodiversity monitoring by community-based restoration groups in New Zealand. Ecological Management \& Restoration, 17(3), 210-17. doi.org/10.1111/emr.12225.

Tanentzap, A. J. and Lloyd, K. M. (2017). Fencing in nature? Predator exclusion restores habitat for native fauna and leads biodiversity to spill over into the wider landscape. Biological Conservation, 214, 119-26. doi.org/10.1016/ j.biocon.2017.08.001.

The National Business Review. (2011). Scientists back Campbell in Moon Man quake prediction row. The National Business Review (Online). Retrieved from www.nbr.co.nz/article/scientists-side-campbell-moon-man-quake-predictiondispute-ck-87208.

Thoresen, J. J., Towns, D., Leuzinger, S., Durrett, M., Mulder, C. P. H. and Wardle, D. A. (2017). Invasive rodents have multiple indirect effects on seabird island invertebrate food web structure. Ecological Applications, 27(4), 1190-98. doi.org/ 10.1002/eap. 1513 .

Trench, B. (2012). Vital and vulnerable: Science communication as a university subject. In B. Schiele, M. Claessens, and S. Shi (eds), Science Communication in the World-practices, theories and trends (pp. 241-57). Springer. doi.org/10.1007/ 978-94-007-4279-6_16.

Twardek, W. M., Peiman, K. S., Gallagher, A. J. and Cooke, S. J. (2017). Fido, Fluffy, and wildlife conservation: The environmental consequences of domesticated animals. Environmental Reviews, 25(4), 381-95. doi.org/10.1139/er-2016-0111.

University of Otago. (2018). The Centre for Science Communication (Online). Dunedin: University of Otago. Retrieved from www.otago.ac.nz/sciencecommunication/about/index.html, doi.org/10.26473/atlaanz.2015.1.1/001.

van Heezik, Y., Smyth, A., Adams, A. and Gordon, J. (2010). Do domestic cats impose an unsustainable harvest on urban bird populations? Biological Conservation, 143(1), 121-30. doi.org/10.1016/j.biocon.2009.09.013.

Walker, J. K., Bruce, S. J. and Dale, A. R. (2017). A Survey of Public Opinion on Cat (Felis catus) Predation and the Future Direction of Cat Management in New Zealand. Animals, 7(7), 49. doi.org/10.3390/ani7070049.

Warner, K. D. (2012). Fighting pathophobia: how to construct constructive public engagement with biocontrol for nature without augmenting public fears. Biocontrol, 57(2), 307-17. doi.org/10.1007/s10526-011-9419-x. 
Wilcox, P. L., Charity, J. A., Roberts, M. R., Tauwhare, S., Tipene-Matua, B., Kereama-Royal, I., Hunter, R., Kani, H. M. and Moke-Delaneyz, P. (2008). A values-based process for cross-cultural dialogue between scientists and Maori. Journal of the Royal Society of New Zealand, 38(3), 215-27. doi.org/10.1080/ 03014220809510555.

Williams, J. (2017). Some approaches to traditional Maori knowledge. Reviews in Anthropology, 46(4), 180-96.

Wilsdon, J. and Willis, R. (2004). See-through science: Why public engagement needs to move upstream. London, Demos.

Zorn, T. E., Roper, J., Weaver, C. K. and Rigby, C. (2012). Influence in science dialogue: Individual attitude changes as a result of dialogue between laypersons and scientists. Public Understanding of Science, 21(7), 848-64. doi.org/10.1177/ 0963662510386292.

\section{Timeline}

\begin{tabular}{|c|c|c|c|}
\hline Event & Name & Date & Comment \\
\hline $\begin{array}{l}\text { First interactive science } \\
\text { centre established. }\end{array}$ & $\begin{array}{l}\text { Otago Museum's } \\
\text { Discovery World in } \\
\text { Dunedin }\end{array}$ & 1991 & \\
\hline $\begin{array}{l}\text { First national (or large } \\
\text { regional) science festival. }\end{array}$ & $\begin{array}{l}\text { International Science } \\
\text { Festival, Dunedin }\end{array}$ & 1998 & \\
\hline $\begin{array}{l}\text { An association of science } \\
\text { writers or journalists } \\
\text { or communicators } \\
\text { established. }\end{array}$ & $\begin{array}{l}\text { Science Communicators } \\
\text { Association of New } \\
\text { Zealand (SCANZ) }\end{array}$ & 2004 & \\
\hline $\begin{array}{l}\text { First university courses } \\
\text { to train science } \\
\text { communicators. }\end{array}$ & $\begin{array}{l}\text { Centre for Science } \\
\text { Communication, Dunedin }\end{array}$ & 2008 & \\
\hline $\begin{array}{l}\text { First master's students in } \\
\text { science communication } \\
\text { graduate. }\end{array}$ & $\begin{array}{l}\text { Centre for Science } \\
\text { Communication, Dunedin }\end{array}$ & 2011 & \\
\hline $\begin{array}{l}\text { First PhD students in } \\
\text { science communication } \\
\text { graduate. }\end{array}$ & Octavia Cade & 2015 & $\begin{array}{l}\text { University of Otago, } \\
\text { Dunedin }\end{array}$ \\
\hline $\begin{array}{l}\text { First national } \\
\text { conference in science } \\
\text { communication. }\end{array}$ & $\begin{array}{l}\text { Assoc. Scientific } \\
\text { and Technical } \\
\text { Communicators (NZ) }\end{array}$ & 1994 & \\
\hline $\begin{array}{l}\text { National government } \\
\text { program to support } \\
\text { science communication } \\
\text { established. }\end{array}$ & $\begin{array}{l}\text { 'Unlocking Curious } \\
\text { Minds' }\end{array}$ & 2015 & \\
\hline
\end{tabular}




\begin{tabular}{|c|c|c|c|}
\hline Event & Name & Date & Comment \\
\hline $\begin{array}{l}\text { First significant initiative } \\
\text { or report on science } \\
\text { communication. }\end{array}$ & $\begin{array}{l}\text { Report of the National } \\
\text { Science Challenges } \\
\text { Panel }\end{array}$ & 2013 & \\
\hline $\begin{array}{l}\text { National Science Week } \\
\text { founded. }\end{array}$ & $\begin{array}{l}\text { National Primary Science } \\
\text { Week }\end{array}$ & 2011 & $\begin{array}{l}\text { Run by The Science } \\
\text { Learning Hub }\end{array}$ \\
\hline $\begin{array}{l}\text { A journal completely or } \\
\text { substantially devoted to } \\
\text { science communication } \\
\text { established. }\end{array}$ & NZ Science Review & 1942 & $\begin{array}{l}\text { Published by the New } \\
\text { Zealand Association } \\
\text { of Scientific Workers } \\
\text { (NZAScW), later NZAS }\end{array}$ \\
\hline $\begin{array}{l}\text { First significant radio } \\
\text { programs on science. }\end{array}$ & $\begin{array}{l}\text { Science Report, Radio } \\
\text { NZ }\end{array}$ & 1957 & \\
\hline $\begin{array}{l}\text { First significant TV } \\
\text { programs on science. }\end{array}$ & $\begin{array}{l}\text { Neil Harraway and } \\
\text { Robert Brown's } \\
\text { documentary on takahe }\end{array}$ & 1974 & $\begin{array}{l}\text { The takahe is a flightless } \\
\text { bird indigenous to New } \\
\text { Zealand }\end{array}$ \\
\hline $\begin{array}{l}\text { First awards for } \\
\text { scientists or journalists } \\
\text { or others for science } \\
\text { communication. }\end{array}$ & $\begin{array}{l}\text { NZAS Science } \\
\text { Journalism award }\end{array}$ & 1980 & \\
\hline $\begin{array}{l}\text { Date hosted a PCST } \\
\text { conference. }\end{array}$ & PCST 2018, Dunedin & 2018 & $\begin{array}{l}\text { 2013: PCST-SCANZ } \\
\text { Symposium, Christchurch }\end{array}$ \\
\hline Other significant events. & $\begin{array}{l}\text { William Doherty, first PhD } \\
\text { student communicating } \\
\text { mātauranga (indigenous } \\
\text { science) }\end{array}$ & 2010 & $\begin{array}{l}\text { Date of graduation, } \\
\text { University of Auckland }\end{array}$ \\
\hline
\end{tabular}

\section{Contributors}

Professor Jean S. Fleming is Professor Emerita of Science Communication at the University of Otago, Dunedin, New Zealand. Jean has led the Popularising Science stream at the Centre for Science Communication for six years.

Professor Nancy Longnecker is Professor of Science Communication at the University of Otago. Before moving to New Zealand, she developed and delivered the science communication course at the University of Western Australia.

Dr Rhian A. Salmon is a senior lecturer and co-leader of the Centre for Science in Society at Victoria University of Wellington in New Zealand. She works as both a practitioner and researcher in public engagement.

Dr Dan C. H. Hikuroa is senior lecturer, Māori Studies, Te Wananga o Waipapa, University of Auckland. He is a world expert on integrating indigenous knowledge and science. 
This text is taken from Communicating Science: A Global Perspective, edited by Toss Gascoigne, Bernard Schiele, Joan Leach, Michelle Riedlinger, Bruce V. Lewenstein, Luisa Massarani and Peter Broks, published 2020 by ANU Press, The Australian National University, Canberra, Australia.

doi.org/10.22459/CS.2020.04 